\title{
Editorial \\ Meteorology: A New Journal for a New Age of Weather Research
}

\author{
Paul D. Williams
}

Department of Meteorology, University of Reading, Reading RG6 6ET, UK; p.d.williams@reading.ac.uk

Citation: Williams, P.D. Meteorology: A New Journal for a New Age of Weather Research. Meteorology 2022, 1, 2-3. https://doi.org/10.3390/ meteorology1010002

Received: 18 February 2022 Accepted: 22 February 2022 Published: 23 February 2022

Publisher's Note: MDPI stays neutral with regard to jurisdictional claims in published maps and institutional affiliations.

Copyright: (C) 2022 by the author. Licensee MDPI, Basel, Switzerland. This article is an open access article distributed under the terms and conditions of the Creative Commons Attribution (CC BY) license (https:/ / creativecommons.org/licenses/by/ $4.0 /)$.
The quest to understand and forecast the weather has occupied human minds since time immemorial. Long before the advent of computers ushered in the modern era of numerical weather prediction, beliefs about meteorology developed that are still part of our folklore today. Examples include "red sky at night, shepherds' delight; red sky in the morning, shepherds' warning" and "cows lie down when it is about to rain" [1]. The revolutionary notion that the weather could be forecast by solving equations based on the laws of physics is only one century old this year [2]. Although subsequent fundamental breakthroughs in meteorology have been rare, the gradual increase in forecast accuracy that has been enabled partly by high-performance computing and extensive observational networks has been nothing short of a "quiet revolution" [3].

It is fitting that a new journal entitled Meteorology [4] is being launched exactly 100 years after Richardson's 1922 seminal contribution [2]. When I was invited to become the founding Editor-in-Chief, I found it astonishing that a journal with that title did not already exist! There are many things about Meteorology that inspired me to accept the invitation. Primarily, the number of fully open-access journals publishing research on meteorology has previously been very limited. This has led to lots of valuable meteorology research being inaccessible to members of the public - and even to scientists who lack the financial resources to purchase journal subscriptions. There is, therefore, a clear need for a fully open-access journal that focusses exclusively on meteorology.

Open access is probably the most significant development in scientific publishing that has occurred in my career so far. Today, many early-career researchers find it hard to believe that previous generations had their access to publicly funded scientific research restricted by paywalls. Open-access publishing is here to stay, and I am glad that Meteorology is at the forefront of this exciting development.

I have an ambitious vision for the journal. Simply put, I would like Meteorology to become one of the top open-access journals that meteorology researchers consider when choosing where to publish their papers. Some of the journal's key strengths-apart from being fully open access-will be our hand-picked and highly qualified Editorial Board, coupled with the fast processing of manuscripts and rapid publication times.

Meteorology is an international, cross-disciplinary, scholarly, peer-reviewed, openaccess journal of research studies related to the science of weather. It publishes review articles as well as regular research papers, without any limits on page length. It also publishes Special Issues on selected themes, and we welcome proposals for these from the international meteorology research community. Meteorology aims to publish the best meteorology research from around the world, whether it is theoretical, numerical, observational, or experimental.

The scope of Meteorology is broad and covers all aspects of weather science, including atmospheric dynamics, atmospheric physics, atmospheric thermodynamics, microscale meteorology, mesoscale meteorology, synoptic-scale meteorology, polar meteorology, midlatitude meteorology, tropical meteorology, applied meteorology, aviation meteorology, agricultural and forest meteorology, renewable energy meteorology, links between weather and air quality, geophysical fluid dynamics, atmospheric models and numerical methods, 
numerical weather prediction, parameterization, weather analysis and forecasting, data assimilation, atmospheric observations, meteorological technology, radar and satellite meteorology, links between weather and land surface processes, urban meteorology, boundary layer meteorology, mountain meteorology, stratospheric meteorology, atmosphere-ocean dynamics, clouds and convection, atmospheric electricity, tropical cyclones, mid-latitude storms, hydrometeorology, turbulence, atmospheric waves, jet streams, radiative transfer, extreme weather, weather in a changing climate, applications of artificial intelligence to meteorology, impacts of geoengineering on weather, and weather modification.

Research into the various aspects of meteorology listed above undoubtedly has a bright future. Meteorology as a scientific discipline has never been more important. The atmosphere is where we live, and the weather within it can vary from pleasant to hazardous-occasionally, it can even be life-threatening. As well as forecasting and understanding weather on timescales from hours to seasons, there is also the question of how climate change will modify meteorological systems, including weather extremes, on timescales from decades to centuries. These are critical research questions with significant societal impacts.

As the founding Editor-in-Chief, I look forward to steering Meteorology on its initial journey into the world, and to watching it grow over time. On behalf of the Editorial Board, I welcome your contributions to the journal, either as authors or reviewers. We are now open for submissions, and we look forward to hearing from you!

Conflicts of Interest: The authors declare no conflict of interest.

\section{References}

1. Met Office Press Release: Do Cows Really Lie Down When It's about to Rain? Available online: www.metoffice.gov.uk/about-us / press-office/news/weather-and-climate/2017/do-cows-really-lie-down-when-its-about-to-rain (accessed on 18 February 2022).

2. Richardson, L.F. Weather Prediction by Numerical Process, 1st ed.; Cambridge University Press: Cambridge, UK, 1922.

3. Bauer, P.; Thorpe, A.; Brunet, G. The quiet revolution of numerical weather prediction. Nature 2015, 525, 47-55. [CrossRef] [PubMed]

4. Meteorology Homepage. Available online: https://www.mdpi.com/journal/meteorology (accessed on 18 February 2022)

\section{Short Biography of Author}

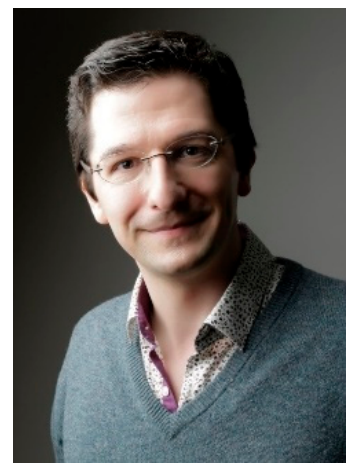

Paul D. Williams is a Professor of Atmospheric Science at the Department of Meteorology at the University of Reading, UK. Since receiving his Ph.D. in Atmospheric Physics from the University of Oxford in 2003, he has specialized in atmospheric modelling, turbulence, jet streams, and climate change. He has pioneered research into the effects of climate change on aviation, showing that severe aircraft turbulence will double or triple in the coming decades. In addition, he has developed turbulence forecasting methods as well as numerical time-stepping schemes for atmospheric models. He has published two books and over 50 peer-reviewed scientific papers in leading journals. 